\title{
Diabetic Animal Models with Infectious Diseases: Focus on the Dysfunction of Immune System
}

\author{
Li-Tzu Yeh1, Yi-Ping Chuang1, Shyi-Jou Chen², Chin-Chen Chu $^{3,4}$ and Huey-Kang Sytwu ${ }^{1 *}$ \\ ${ }^{1}$ Department and Graduate Institute of Microbiology and Immunology, National Defense Medical Center, Taiwan \\ ${ }^{2}$ Department of Pediatrics, Tri-Service General Hospital, Taiwan \\ ${ }^{3}$ Department of Anesthesiology, Chi Mei Medical Center, Tainan, Taiwan \\ ${ }^{4}$ Department of Recreation and Health-Care Management, Chia Nan University of Pharmacy and Science, Tainan, Taiwan
}

\begin{abstract}
Diabetes Mellitus (DM) is a metabolic disease that can lead to a variety of complications, such as neuropathy, retinopathy, nephropathy, and cardiovascular disease. Furthermore, pathogen infection accompanied by considerable morbidity and mortality is common among diabetic patients. Increased susceptibility to pathogen infection results from impaired immune responses, such as lower cytokine production and reduced function or migration of immune cells. However, existing clinical data remains controversial because multiple diabetes-related factors such as obesity, hyperglycemia, hyperinsulinemia, and other comorbidities also increase the risk of infection. In recent decades, several animal models have been used to investigate the role played by immune dysfunction in increasing susceptibility to pathogens and related diseases in diabetes. This review focuses on studies that used diabetic animal models to study infectious diseases and summarizes potential mechanisms underlying dysfunction of the immune system in diabetes patients.
\end{abstract}

\section{Introduction}

Worldwide, the number of people suffering from diabetes mellitus increased from 153 million to approximately 347 million between 1980 and 2008 [1]. Estimates predict that the global prevalence of diabetes will reach $366-440$ million by 2030 [2]. Diabetic patients are more susceptible to infection by certain microorganisms, such as Staphylococcus aureus, Klebsiella pneumoniae, and Mycobacterium tuberculosis $(M t b)$ [3], and these infections often require hospitalization. One recent study calculated the cause-specific risk of death in 820,900 people according to diabetes status or fasting glucose level [4]. Those authors found that the hazard ratios of mortality from infectious diseases (excluding pneumonia) ranked second only to renal disease as a cause of noncancerous and nonvascular death in diabetes patients.

Previous clinical investigations and experimental studies using diabetic rodent models have shown that the dysfunctional immune system of diabetes patients leads to increased susceptibility to pathogens and infections of greater severity. Those research identified various impairments to innate immunity in DM patients, including reduced production of inflammatory cytokines and loss of function (chemotaxis, phagocytosis, superoxide production, or killing activity) in neutrophils, macrophages or natural killer cells [5-7]. Defects in adaptive immunity have also been reported in diabetic patients, including: abnormal delayed-type hypersensitivity, attenuation of lymphocyte proliferation, and decreased serum antibody levels [8-11]. However, diabetes is a metabolic disease that is often accompanied by abnormalities, which impair the resistance to pathogenic infections, such as chronic inflammation and associated alterations to the lipid profile, neuropathy, and chronic vascular or renal diseases [12]. Therefore, the mechanism underlying the role played by the immune system in high susceptibility to pathogen infection among diabetes patients are still far from established.

For decades, animal models have been used to investigate the pathophysiology of Type 1 and Type 2 diabetes (T1D and T2D) for the development of therapeutic treatment strategies. More recently, diabetic animal models have been applied to investigate how immune dysfunction contributes to infection among diabetes patients. Most previous studies have focused on Tuberculosis (TB) and sepsis; however, reports of diabetes-related infections such as pneumonia, Urinary Tract Infections (UTI), Surgical Site Infections (SSI), or infections on the feet have provided intriguing data, which have indicated various mechanisms that could explain the defective immune responses. In this review, we classify diabetic animal models according to various infectious diseases and describe the microorganisms and diabetic models used in diabetes studies. We also discuss various mechanisms associated with immune dysfunction, in order to identify cellular and/ or molecular properties that could be promising therapeutic targets for future research and treatment of diabetes.

\section{Diabetic Animal Models of Various Infectious Diseases}

\section{Diabetic animal models of respiratory infections}

Tuberculosis pneumonia: $M t b$, a bacterial species in the Mycobacteriaceae family, is the causative agent in most cases of TB. Approximately $10 \%$ of $M t b$-infected patients develop an active disease as a result of inherited and acquired risk factors, including human immunodeficiency virus, malnutrition, alcohol use, smoking, and indoor air pollution. Recently, diabetes has been deemed a risk for the growing number of TB worldwide, and the World Health Organization estimates that the current number of diabetes patients ( 347 million) will double by 2030 [13]. Therefore, the combination of TB and diabetes represents a worldwide health threat, and identifying potential mechanisms by which DM increases TB incidence is crucial to deal with this.

*Corresponding author: Huey-Kang Sytwu, Department and Graduate Institute of Microbiology and Immunology, National Defense Medical Center, Taiwan, Tel: 02 8792-3100 \#18539; Fax: 02-8792-1774; E-mail: sytwu@ndmctsgh.edu.tw

Received June 28, 2014; Accepted August 23, 2014; Published August 29, 2014

Citation: Yeh LT, Chuang YP, Chen SJ, Chu CC, Sytwu HK (2014) Diabetic Animal Models with Infectious Diseases: Focus on the Dysfunction of Immune System. J Diabetes Metab 5: 417 doi:10.4172/2155-6156.1000417

Copyright: (๑) 2014 Yeh LT, et al. This is an open-access article distributed under the terms of the Creative Commons Attribution License, which permits unrestricted use, distribution, and reproduction in any medium, provided the original author and source are credited. 
In the 1980s, Saiki et al. [14] demonstrated that streptozotocin (STZ)-induced diabetic ICR mice suffered an increase in mortality when injected intravenously with live Mtb (Schacht strain) $(90 \%$ mortality among diabetic mice compared with $10 \%$ among normal mice). Their study revealed that $\mathrm{T}$-cell function and phagocytic activity of macrophages were depressed in STZ-induced diabetic mice; however, B-cell function and intracellular killing of macrophages remained normal. Neither ketoacidosis nor ketone bodies were detected in diabetic mice, suggesting that the defective immune function was associated with hyperglycemia.

In 2004, Sugawara et al. [15] infected GK/Jcl rats, a T2D animal model, with $M t b$ (Kurono strain) via the airborne route to mimic the natural pathway of TB infection. They found that GK/Jcl diabetic rats had more colony-forming unit cells in lung and spleen tissues than did non-diabetic Wistar rats [15]. Furthermore, the production of TNF- $\alpha$, IL-12, and Nitric Oxide (NO) was lower in the alveolar macrophages obtained from diabetic rats, compared with control rats [15]. Those findings suggest that low expression of inflammatory cytokines and NO coupled with incomplete macrophage activation allows granulomas to grow larger than normal. Similar results were observed in STZ-induced diabetic ICR mice intravenously infected with $M t b$ (H37Rv strain). The authors of that study suggested that reduced expression of IL-12, a critical inducer of IFN- $\gamma$, was the primary reason for the inhibition of iNOS expression, and thus also explained the increased susceptibility of diabetic mice to $M t b$ infection. In another study, insulin therapy was shown to lower the blood glucose level of diabetic mice and appeared to improve bacterial clearance, implying that hyperglycemia (but not STZ itself) was involved in impairing host immune responses against $M t b$ [16]. Collectively, the aforementioned studies demonstrated that defects of innate immune responses, such as lower production of Th1-related cytokines and $\mathrm{NO}$ as well as reduced macrophage function, limit the ability of diabetic hosts to defend against $M t b$ infection.

In 2007, Martens et al. [17] demonstrated the participation of adaptive immune response to $M t b$ infection (Erdman strain) in STZinduced diabetic C57BL/6 mice. They observed that chronically diabetic mice are more susceptible to $M t b$ infection than are acute diabetic mice. Although the levels of IFN- $\gamma$, IL- $1 \beta$ and TNF- $\alpha$ were higher in lung lysates of chronically diabetic mice with $M t b$ infection, the production of IFN- $\gamma$ in lung leukocytes re-stimulated with Con A, anti-CD3, or $M t b$ antigens decreased ex vivo. Those results suggest that impairments to adaptive immune function in chronic hyperglycemia patients are associated with increased susceptibility to $M t b$ infection in the lung. Strengthening that hypothesis, Ins $2^{\text {Akita }}$ (Akita) mice were found to spontaneously become hypoinsulinemic and hyperglycemic at 3 to 4 weeks of age. The same research group recently demonstrated that increased TB susceptibility in chronic STZ-induced diabetic mice is the result of a delay in the innate immune response to $M t b$-infected alveolar macrophages [18]. This in turn drains the lymph nodes, delays the delivery of antigen-bearing antigen-presenting cells to the lung, and delays priming of the adaptive immune response. These immunerelated activities are all necessary for the restriction of $M t b$ replication.

Multiple studies have shown that susceptibility to $M t b$ infection increases in diabetes patients and that dysfunction in both innate and adaptive immune responses may be the cause (Table 1). Nonetheless, the underlying mechanism behind immune dysfunction in diabetes remains unclear. Recently, Podell et al. [19] demonstrated that nondiabetic hyperglycemia exacerbates the severity of $M t b$ infection in guinea pigs. They also suggested that Advanced Glycation End Products (AGEs) are the link between hyperglycemia and immune dysfunction in diabetes patients. However, additional evidence is required to confirm this hypothesis.

Other bacterial pneumonia: Diabetic patients also face increased risk of mortality due to pneumonia (hazard ratio, 1.67) [4]. In the 1960s, Drachman et al. [20] demonstrated that the death rate attributable to type 25 pneumococci infections is higher in alloxaninduced diabetic rats than in non-diabetic rats, due to an overgrowth of bacteria in pulmonary lesions. The inability of diabetic rats to control bacterial growth is due primarily to a reduction in the phagocytic capabilities of leukocytes. Data from in vitro experiments indicates that hyperglycemia-induced hyperosmolarity is the depressive factor associated with inferior phagocytic defense [20]. To mimic the natural path of pneumococcus infection, Hebert et al. [21] exposed alloxaninduced diabetic mice to an aerosol containing $10^{8}$ type III Streptococcus pneumoniae $/ \mathrm{ml}$, and monitored the ability of the pulmonary barrier to defend against infection. In that study, the survival rate of diabetic mice was lower than that of non-diabetic mice. However, insulin treatment significantly increased the survival rate of diabetic mice, suggesting that insulin therapy could help to control pulmonary infection in diabetes patients. Other earlier work also showed that phagocytic functions including chemotaxis, phagocytosis, and the adhesion of leukocytes to the endothelium, are impaired in diabetes patients [22-24]. Authors of one study therefore suggested that impaired macrophage function may account for the high susceptibility to pulmonary infection. Another

\begin{tabular}{|c|c|c|c|c|}
\hline Animal models & $\begin{array}{l}\text { Characterization of infections in diabetic } \\
\text { mice }\end{array}$ & Infection route & $\begin{array}{l}\text { Cellular or molecular observation in } \\
\text { diabetic mice with TB }\end{array}$ & Reference \\
\hline $\begin{array}{l}\text { STZ (200 } \mathrm{mg} / \mathrm{kg}) \text {-induced diabetes } \\
\text { in ICR mice (T1D) with Mtb (Schacht } \\
\text { strain) infection }\end{array}$ & $\begin{array}{l}\text { Reduced survival time and decreased } \\
\text { survival incidence after } M \text { tb infection }\end{array}$ & Intravenous injection & $\begin{array}{l}\text { Depression of T cell function and macrophage } \\
\text { phagocytosis }\end{array}$ & [14] \\
\hline $\begin{array}{l}\text { GK/ Jcl rat (T2D) with Mtb (Kurono } \\
\text { strain) infection }\end{array}$ & $\begin{array}{l}\text { Larger granulomas, higher colony- forming } \\
\text { units count in lung and spleen tissues after } \\
\text { infection for } 3 \text { weeks }\end{array}$ & Airborne route infection & $\begin{array}{l}\text { Less TNF- } \alpha, \text { IL-12 secretion and NO production } \\
\text { in alveolar macrophages stimulated with } M t b .\end{array}$ & [15] \\
\hline $\begin{array}{l}\text { STZ }(150 \mathrm{mg} / \mathrm{kg}) \text {-induced diabetes in } \\
\text { ICR mice (T1D) with Mtb (H37Rv strain) } \\
\text { infection }\end{array}$ & $\begin{array}{l}\text { Increased bacterial loads in lung, liver and } \\
\text { spleen }\end{array}$ & $\begin{array}{l}\text { Intravenous } \\
\text { injection }\end{array}$ & $\begin{array}{l}\text { Less expression level of Th1-related cytokines } \\
\text { and iNOS in lung, liver and spleen }\end{array}$ & [16] \\
\hline $\begin{array}{l}\text { STZ (150 mg/kg)-induced diabetes in } \\
\text { C57BL/6 mice (T1D) with Mtb (Erdman } \\
\text { strain) infection } \\
\text { Akita mice (T1D) with Mtb (Erdman } \\
\text { strain) infection }\end{array}$ & $\begin{array}{l}\text { Higher bacterial lung burden and increased } \\
\text { extent of lung inflammation }\end{array}$ & Airborne route infection & $\begin{array}{l}\text { Increase in IFN- } y \text { and inflammatory cytokines } \\
\text { in pooled lung lysates. Reduced antigen- } \\
\text { specific and -nonspecific IFN- } y \text { production in } \\
\text { lung } T \text { cells. }\end{array}$ & {$[17,18]$} \\
\hline $\begin{array}{l}\text { Diet-induced hyperglycemia in non- } \\
\text { diabetic guinea pig (non-DM) with } M t b \\
\text { (H37Rv strain) infection }\end{array}$ & $\begin{array}{l}\text { Higher lung and extrapulmonary Mtb lesion } \\
\text { burden in sucrose- } \\
\text { induced hyperglycemia guinea pig }\end{array}$ & Airborne route infection & $\begin{array}{l}\text { Hyperglycemia-mediated AGE accumulation } \\
\text { in lung }\end{array}$ & [19] \\
\hline
\end{tabular}

Table 1: Comparison of the characteristics and immune dysfunction in diabetic mouse models of TB pneumonia. 
recent study demonstrated that diabetes increases the risk of Chlamydia pneumoniae spreading from the lung to the peripheral blood in NOD mice [25]. In last two decades, several studies demonstrated that C. pneumoniae is associated with the development atherosclerosis $[26,27]$, suggesting that increased dissemination of C. pneumoniae may accelerate the formation of atherosclerotic plaques in diabetes. A relationship between diabetes and pneumonia-related death has been established; however, current animal models are inadequate to identify underlying mechanisms. Thus, the development of new animal models is urgently required to elucidate these effects and facilitate the development of effective clinical treatments.

\section{Diabetic animal models of urinary tract infections}

The risk of UTIs, including those of the bladder (cystitis) and kidney (pyelonephritis), is increased in diabetes patients, and many infected diabetic patients commonly suffer from UTI-related complications [28]. Although immune system defects have been suggested to contribute to diabetic UTIs, few studies have established this link directly. Rosen et al. [29] used a STZ-induced diabetic mouse model to investigate the susceptibility of diabetic animals to uropathogenic Escherichia coli, the most common etiological agent of UTIs. Those researchers found that the burden of infections by E. coli (UT189), K. pneumoniae (TOP52), and Enterococcus faecalis (0852) in the bladder and kidney are more severe in diabetic mice than in non-diabetic mice. Moreover, compared with $E$. coli, the prevalence of $K$. pneumoniae was higher in the bladder. Those results were consistent with the epidemiological findings in diabetic patients. In addition, the E. coli titers in bladders of Toll-like receptor 4 (TLR-4) mutant mice $(\mathrm{C} 3 \mathrm{H} / \mathrm{HeJ}$ strain) were less than that of normal mice $(\mathrm{C} 3 \mathrm{H} / \mathrm{HeN}$ strain), indicating that TLR-4-regulated cells are associated with increased susceptibility to UTIs [29]. Nevertheless, increased susceptibility to UTI infection was still observed in diabetic $\mathrm{C} 3 \mathrm{H} / \mathrm{HeJ}$ mice, suggesting that other TLR-4-independent factors are also involved in diabetes-related UTI.

\section{Diabetic animal models of foot infection}

Foot infections following skin ulceration commonly require hospitalization and are the most common cause of lower-extremity amputations among diabetic patients [30]. Although diabetic foot infections are polymicrobial, Staphylococcus aureus (S. aureus) is frequently implicated [31]. To investigate the pathogenesis of foot infections in diabetes, one research group developed diabetic foot infection animal models by inoculating the hind paw of NOD mice (T1D) [32] and $d b / d b$ mice (T2D) with $S$. aureus [33]. In those studies, diabetic mice exhibited more severe foot infection than did non-diabetic mice. The control of glycemia was helpful to improve $S$. aureus clearance and leukocytes bacterial activity, suggesting that hyperglycemia is a risk factor to increase the susceptibility to foot infections in diabetes. Moreover, in the early stages of bacterial infection, the expression of chemokines such as KC and MIP-2 was shown to decrease, and fewer polymorphonuclear leukocytes reached the infected hind paw of diabetic NOD mice. The authors hypothesized that delayed innate immune responses allowed invading bacteria to gain a foothold in the tissue of diabetic mice. However, delayed immune responses were not observed in diabetic $d b / d b$ mice, suggesting that the mechanism underlying immune dysfunction in the two types of diabetes are not necessarily the same.

\section{Diabetic animal models of surgical site infection}

The frequency of surgical site infection is higher in diabetes patients than in healthy individuals [34-36]. SSI can lead to the failure of medical implants such as prosthetic joints, implantable cardioverter defibrillators, urinary catheters, orthopedic implants, breast implants, and glucose sensors [37]. To investigate the effect of insulin treatment on SSI and neutrophil function, one research group recently developed T2D models of $S$. aureus SSI in $d b / d b$ mice and mice that were fed a high-fat-diet (HFD-fed mice) [38]. Those authors demonstrated that SSIs in diabetic $d b / d b$ mice and hyperglycemic HFD-fed mice were more severe than in non-diabetic and euglycemic mice, respectively. However, insulin treatment decreased the severity of SSI substantially and also improved the ability of neutrophils to kill S. aureus. Moreover, ex vivo insulin treatment largely restored neutrophil function and ameliorated SSI, suggesting that insulin may activate neutrophil function directly [38]. More recently, Lovati et al. [39] used a NOD mice model to investigate the susceptibility of T1D animals to orthopedic implant-related S. aureus infection. Those authors observed more severe osteomyelitic change surrounding the implant in diabetic NOD mice than in control mice. Although the immune cells responsible for increased susceptibility to implant-related infection were not identified, this study still provided a useful animal model for related studies.

\section{Diabetic animal models of sepsis}

A variety of diabetic animal model has been developed to investigate the pathophysiology of sepsis, due to the fact that sepsis accounts for the highest risk ratio among all infectious diseases requiring that diabetic patients undergo hospitalization [40]. In the early 1980s, Kitahara et al. [41] demonstrated the association between diabetes and sepsis by inoculating STZ-induced diabetic mice with Pseudomonas aeruginosa (P. aeruginosa) [41]. No difference in in mortality was observed between diabetic and control mice; however, reduced resistance to bacterial growth was observed in the liver, spleen, kidney and peripheral blood of diabetic mice. The protective activities of blood serum from vaccinated diabetic mice were significantly lower than that from vaccinated nondiabetic mice, suggesting a link between resistance to $P$. aeruginosa infection and antibody- or cytokine-mediated immunity. The diabetic mice that received serum from normal vaccinated mice also showed a decrease in resistance to bacterial growth, suggesting the existence of abnormalities in immune cells against $P$. aeruginosa infection. In addition, reduced resistance to sepsis induced by Group B streptococci (GBS) was consistently observed in diabetic mice. The higher mortality rate associated with GBS-induced sepsis in diabetic mice was likely due to dysregulation of the cytokine network and prolonged local inflammatory responses [42].

In a study of Akita mice using a spontaneous T1D model, the mortality rate associated with Cecal Ligation and Puncture (CLP) induced-sepsis was exacerbated [43]. Authors of those results demonstrate that increased mortality among diabetic mice is not dependent on the pre-lethal activation of cytokines but rather coincides with a widespread reduction in the inflammatory response [43]. In addition, Jacob et al. [44] used a Goto-Kakizaki (GK) rat T2D animal model, to investigate sepsis-induced inflammation in animals that underwent CLP [44]. Those authors observed higher levels of plasma IL-6 and IL-10 in diabetic GK rats than in non-diabetic Wistar-Kyoto rats at 20 hours post-CLP, suggesting a relationship between T2D and sepsis-induced inflammation.

In addition to the dysregulation of cytokine production, defective neutrophil function has also been associated with the severity of sepsis in both diabetic patients and diabetic animal models. Spiller et al. [45] demonstrated that alloxan-induced diabetic mice are highly susceptible to polymicrobial-induced sepsis due to reductions in rolling, adhesion, 
Citation: Yeh LT, Chuang YP, Chen SJ, Chu CC, Sytwu HK (2014) Diabetic Animal Models with Infectious Diseases: Focus on the Dysfunction of Immune System. J Diabetes Metab 5: 417 doi:10.4172/2155-6156.1000417

and migration of neutrophils. They also observed G-protein-coupled receptor kinase-2 (GRK2)-mediated downregulation of CXCR-2 in blood neutrophils and higher expression of al-acid glycoprotein (AGP) in the serum of diabetic mice, compared with control mice [45]. Moreover, administration of AGP eliminated the protective effects of insulin in diabetic mice, suggesting that a diabetes-insulin-sepsis-AGP axis is involved in regulating the migration of neutrophils to infection sites [45]. The same research team recently demonstrated that mast cells also participate in the increased susceptibility of diabetic mice to septic peritonitis. Specifically, the histamine released by mast cells appears to impair neutrophil migration through histamine $\mathrm{H}_{2}$ receptor signaling [46].

Collectively, studies involving various diabetic animal models support the idea that diabetic hosts are more susceptible to microbialinduced bacteremia or sepsis (Table 2). Insulin treatment and appropriate glycemic control can increase the resistance to sepsis in diabetic individuals and animals. Additionally, impaired neutrophil migration resulting from mast cell degranulation may partially responsible for the increase in the severity of sepsis among diabetes patients. Other impaired neutrophil functions, such as chemotaxis and reduced phagocytic capacity, have also been described in diabetic hosts. In the future, a more comprehensive suite of immune cell functions should be investigated in order to extend our knowledge of how immune dysfunction affects microorganism-induced sepsis in diabetes patients.

\section{Diabetic animal models of melioidosis}

Melioidosis is an emerging tropical infectious disease with high incidence and mortality rate in northern Australia and south-east Asia. Diabetic patients with preexisting or newly diagnosed T2D have a high incidence of melioidosis accompanied by pneumonia and septic shock [47-51]. Hodgson et al. [52] used $d b / d b$ mice to investigate the dysfunction of immune responses underlying high susceptibility of melioidosis in T2D [52]. They observed that mice with T2D are more susceptible to Burkholderia pseudomallei (B. pseudomallei)-induced mortality accompanied by increased expression of inflammatory cytokines and hypoglycemia which is the response often observed in bacterial sepsis. The decrease of phagocytic and antimicrobial activities in macrophages from diabetic mice may contribute to the failure of controlling bacterial dissemination and disease progression. Recently, the same group generated a polygenic diet-induced diabetes model that more closely resembles the clinical criteria of T2D to investigate DM and melioidosis comorbidity [53]. Similarly, their results indicate that the impaired immune pathways contribute to the increased susceptibility to bacterial infection in diabetic mice. In addition to T2D, Williams et al. [54] used STZ-induced T1D model to demonstrate that uncontrolled hyperglycemia impairs Bone Marrow-Derived Dendritic Cells (BMDCs) and macrophage to internalize and kill $B$. pseudomallei and generate cytokine profiles not favor Th1-type immune response [54]. Collectively, these studies demonstrate how diabetes status and hyperglycemia affect the ability of BMDCs and macrophages to clear B. pseudomallei. Although the mechanisms underlying immune dysfunction are still unclear, these studies establish suitable animal models to investigate diabetes and melioidosis comorbidity.

\begin{tabular}{|c|c|c|c|c|}
\hline Animal models & $\begin{array}{l}\text { Characterization of symptoms } \\
\text { in diabetic mice }\end{array}$ & $\begin{array}{l}\text { Infection route or sepsis } \\
\text { induction }\end{array}$ & $\begin{array}{l}\text { Cellular or molecular observation in } \\
\text { diabetic mice with sepsis }\end{array}$ & Reference \\
\hline $\begin{array}{l}\mathrm{STZ} \quad(140 \quad \mathrm{mg} / \mathrm{kg}) \text {-induced } \\
\text { diabetes in CF1 mice (T1D) with } P . \\
\text { aeruginosa (NC-5 strain) infection }\end{array}$ & $\begin{array}{l}\text { No increase in acute death } \\
\text { rate. Increase in the number of } \\
\text { bacteria in kidney, liver, spleen } \\
\text { and peripheral blood. }\end{array}$ & Intravenous injection & $\begin{array}{l}\text { (i) Less effect of pass protection in immune serum from } \\
\text { diabetic vaccinated mice in normal recipients, implying the } \\
\text { impairment of antibody- or cytokine-mediated immunity. } \\
\text { (ii) Less effect of protection in immune serum from normal } \\
\text { vaccinated mice into diabetic recipients, implying the } \\
\text { impairment of immune cells-mediated immunity }\end{array}$ & [41] \\
\hline $\begin{array}{l}\text { STZ }(50 \mathrm{mg} / \mathrm{kg} \text { for } 5 \text { consecutive } \\
\text { days)-induced diabetes in CD-1 } \\
\text { mice (T1D) with type VI GBS } \\
\text { (NCTC } 1 / 82 \text { strain) infection }\end{array}$ & $\begin{array}{l}\text { Lower } 50 \% \text { lethal dose (>1 } \\
\text { log10 in CFU). Increase in } \\
\text { bacterial growth in blood and } \\
\text { kidney. }\end{array}$ & $\begin{array}{l}\text { Intravenous } \\
\text { injection }\end{array}$ & $\begin{array}{l}\text { Increase in IL- } 6 \text {, IL-1 } \alpha \text {, IL-10, TNF- } \gamma \text { and decrease in IFN- } \gamma \\
\text { levels in the serum of diabetic mice with sepsis. }\end{array}$ & [42] \\
\hline $\begin{array}{l}\text { Goto Kakizaki (GK) rats (T2D) with } \\
\text { CLP }\end{array}$ & Not validated & CLP-induced sepsis & $\begin{array}{l}\text { Increase in plasma lactate, IL-6 and IL-10 } 20 \mathrm{hr} \text { after CLP in } \\
\text { diabetic mice with sepsis }\end{array}$ & [44] \\
\hline AKITA mice (T1D) with CLP & $\begin{array}{l}\text { Increase in the sepsis-induced } \\
\text { mortality }\end{array}$ & CLP-induced sepsis & $\begin{array}{l}\text { (i) Greater number of circulating neutrophils at first } 24 \mathrm{hr} \text { after } \\
\text { CLP in diabetic mice. } \\
\text { (ii) Decrease in pro-inflammatory and anti-inflammatory } \\
\text { cytokines in diabetic mice compared with died mice. }\end{array}$ & [43] \\
\hline $\begin{array}{l}\text { Alloxan }(50 \mathrm{mg} / \mathrm{kg}) \text {-induced } \\
\text { diabetes in BALB/C mice or in } \\
\text { C57BL/6 mice (T1D) } \\
\text { with CLP }\end{array}$ & $\begin{array}{l}\text { Increase in polymicrobial } \\
\text { sepsis-induced mortality and } \\
\text { the number of bacterial load in } \\
\text { peritoneal cavity lavage or blood }\end{array}$ & CLP-induced sepsis & $\begin{array}{l}\text { (i) Reduction in rolling, adhesion and migration of leukocytes } \\
\text { to the sites of infection. } \\
\text { (ii) Downregulation of CXCR2 and upregulation of GRK2 in } \\
\text { the neutrophils. } \\
\text { (iii) Impairment in intracellular adhesion molecule-1 } \\
\text { expression on endothelium } \\
\text { (vi) Increase in AGP serum protein levels. }\end{array}$ & [45] \\
\hline $\begin{array}{l}\text { Alloxan (50 mg/kg)-induced } \\
\text { diabetes in BALB/c mice with CLP } \\
\text { NOD mice (T1D) with CLP }\end{array}$ & $\begin{array}{l}\text { (i) Acceleration of polymicrobial } \\
\text { sepsis-induced mortality and } \\
\text { increase of bacterial load in } \\
\text { peritoneal cavity lavage or blood } \\
\text { (ii) C48/80 or histamine } \\
\text { receptor antagonist treatment or } \\
\text { monocytes deficiency reversed } \\
\text { the acceleration of sepsis- } \\
\text { induced mortality } \\
\text { and bacterial loading in } \\
\text { peritoneal cavity lavage or blood }\end{array}$ & CLP-induced sepsis & $\begin{array}{l}\text { (i) Reduce in neutrophil migration to the sites of infection. } \\
\text { (ii) Downregulation of CXCR2 and upregulation of GRK2 in } \\
\text { the neutrophils } \\
\text { (iii) C } 48 / 80 \text { or histamine receptor antagonist treatment or } \\
\text { monocytes deficiency increased CXCR2 expression in the } \\
\text { neutrophils } \\
\text { (iii) C48/80 treatment prevented GRK2 induction in the } \\
\text { neutrophils }\end{array}$ & {$[46]$} \\
\hline
\end{tabular}

Table 2: Comparison of the characteristics and immune dysfunction in diabetic mouse models of sepsis. 
Citation: Yeh LT, Chuang YP, Chen SJ, Chu CC, Sytwu HK (2014) Diabetic Animal Models with Infectious Diseases: Focus on the Dysfunction of Immune System. J Diabetes Metab 5: 417 doi:10.4172/2155-6156.1000417

Page 5 of 6

\section{Conclusions}

The development of animal models for specific clinical diseases has been and will remain critical to our understanding of the pathophysiology of diseases and the development of novel therapeutic strategies to treat them. This review included a variety of diabetic animal infection models used to investigate immune dysfunction and diabetes-related infection. To summarize, STZ- and alloxan-induced T1D models have been widely used to investigate the susceptibility to and pathophysiology of various infectious diseases. The advantage of these models is that the development of hyperglycemia is uniform and controllable in different murine backgrounds. Moreover, STZ or alloxan-induced T1D can be used in knockout or mutant mice to identify mechanisms which may be responsible for increased susceptibility to infection. T2D animal models have also been used to investigate how immune dysfunction affects diabetes-related infections. The $d b / d b$ mice with genetic mutation in leptin signaling are frequently used in different studies. However, the effect of leptin signaling deficiency on hormonal imbalance and immune system may complex the study of immune complications related to T2D. Hodgson et al. [53] therefore developed a polygenic model of diet-induced T2D that more closely reflect dietary intake in developed nations to investigate melioidosis [53]. In addition to the influence of leptin signaling mutation, researchers using T2D model observed the hyperproductivity of superoxide by neutrophils in HFD mice but not in $d b / d b$ mice [38]. Patients suffering from T2D have elevated levels of proinflammatory cytokines, which can increase superoxide production in neutrophils [55]. This suggests that HFD mice may be the most appropriate animal model for the investigation of pathogen infection in T2D patients [38]. Finally, infections of greater severity have been observed in diabetic $d b / d b$ mice as well as hyperglycemic HFD-fed mice, future investigators should take into account the differential superoxide production by neutrophils between these two models.

Many studies using diabetic animal models have focused on TB or microbial-induced sepsis on TB or microbial-induced sepsis. Those findings are in line with other animals models of diabetes-related infection, which show that diabetes and hyperglycemia can impair both innate and adaptive immune responses and thereby reduce resistance to pathogen infection and other associated diseases. Insulin treatment and proper glycemic control can help to reduce the amount of bacteria within lesions and ameliorate the severity of diseases. However, future researchers investigating immune response in diabetes subjects should consider the duration of diabetes because cytokine production differs between the acute and chronic stages of the disease. Although hyperglycemia has been shown to increase the dysfunction of phagocytes such as neutrophils or macrophages, and thus reduce resistance to different infections, the molecular mechanisms underlying these impairments remain largely unknown. Studies provided possible models of immune dysfunction in diabetes-related infection $[45,46]$. In addition, the immune system of diabetic subjects may be impaired by primary defects such as: (1) hyperglycemia-induced abnormalities in osmotic processes, (2) the accumulation of AGEs (3) high levels of AGP in serum, and (4) impairment of glucose metabolism in neutrophils. Interestingly, the effects of these defects may be in opposition to obesityassociated increase of adipose resident macrophages inflammation. In obese state, the increase accumulation of macrophage correlates with increased cytokines and chemokines. Leptin is a adipokine important in modulating the function of macrophages [56]. In obese $o b / o b$ mice with $M t b$ infection, deficiency in leptin may attenuate the function of macrophage and IFN- $\gamma$-driven Th1 responses [57]. However, the adipose resident macrophages phenotypically resemble $\mathrm{M} 2$ macrophage and can produce anti-inflammatory cytokines, suggesting that the role of these cells in regulating immune responses in diabetes remain to be elucidated [58]. Future research should seek to further elucidate the effects of these abnormalities on immune system in patients suffering from diabetes.

\section{Acknowledgments}

This work was supported by National Science Council grants NSC102 2321-B-016-006, MOST 103-2321-B-016-001, MOST 103-2320-B-016-017-MY3, NSC103-2321-B-001-051; Tri-Service General Hospital grants TSGH-C103-005007-009-S01; Chi Mei Medical Center (CMNDMC10301) and C.Y. Foundation for Advancement of Education, Sciences, and Medicine grant

\section{References}

1. Danaei G, Finucane MM, Lu Y, Singh GM, Cowan MJ, et al. (2011) National, regional, and global trends in fasting plasma glucose and diabetes prevalence since 1980: systematic analysis of health examination surveys and epidemiological studies with 370 country-years and 2.7 million participants. Lancet 378: 31-40.

2. Wild S, Roglic G, Green A, Sicree R, King H (2004) Global prevalence of diabetes: estimates for the year 2000 and projections for 2030. Diabetes Care 27: 1047-1053.

3. Joshi N, Caputo GM, Weitekamp MR, Karchmer AW (1999) Infections in patients with diabetes mellitus. N Engl J Med 341: 1906-1912.

4. Emerging Risk Factors Collaboration, Seshasai SR, Kaptoge S, Thompson A Di Angelantonio E, et al. (2011) Diabetes mellitus, fasting glucose, and risk of cause-specific death. N Engl J Med 364: 829-841.

5. Geerlings SE, Hoepelman Al (1999) Immune dysfunction in patients with diabetes mellitus (DM). FEMS Immunol Med Microbiol 26: 259-265.

6. Alba-Loureiro TC, Munhoz CD, Martins JO, Cerchiaro GA, Scavone C, et al. (2007) Neutrophil function and metabolism in individuals with diabetes mellitus. Braz J Med Biol Res 40: 1037-1044.

7. Berrou J, Fougeray S, Venot M, Chardiny V, Gautier JF, et al. (2013) Natural killer cell function, an important target for infection and tumor protection, is impaired in type 2 diabetes. PLoS One 8: e62418.

8. Casey JI, Heeter BJ, Klyshevich KA (1977) Impaired response of lymphocytes of diabetic subjects to antigen of Staphylococcus aureus. J Infect Dis 136: 495 501

9. Maccuish A C, Urbaniak S J, Campbell C J, Duncan L Jlrvine W J (1974) Phytohemagglutinin transformation and circulating lymphocyte subpopulations in insulin-dependent diabetic patients. Diabetes 238: 708-712.

10. Moutschen M P, Scheen A JLefebvre P J (1992) Impaired immune responses in diabetes mellitus: analysis of the factors and mechanisms involved. Relevance to the increased susceptibility of diabetic patients to specific infections. Diabete Metab 183: 187-201.

11. Beam TR Jr, Crigler ED, Goldman JK, Schiffman G (1980) Antibody response to polyvalent pneumococcal polysaccharide vaccine in diabetics. JAMA 244 2621-2624.

12. Graves DT, Kayal RA (2008) Diabetic complications and dysregulated innate immunity. Front Biosci 13: 1227-1239.

13. Maurice J (2011) WHO framework targets tuberculosisâ€"diabetes link. Lancet 378: $1209-1210$

14. Saiki O, Negoro S, Tsuyuguchi I, Yamamura Y (1980) Depressed immunological defence mechanisms in mice with experimentally induced diabetes. Infect Immun 28: 127-131.

15. Sugawara I, Yamada H, Mizuno S (2004) Pulmonary tuberculosis in spontaneously diabetic goto kakizaki rats. Tohoku J Exp Med 204: 135-145.

16. Yamashiro S, Kawakami K, Uezu K, Kinjo T, Miyagi K, et al. (2005) Lower expression of Th1-related cytokines and inducible nitric oxide synthase in mice with streptozotocin-induced diabetes mellitus infected with Mycobacterium tuberculosis. Clin Exp Immunol. 1391: 57-64.

17. Martens GW, Arikan MC, Lee J, Ren F, Greiner D, et al. (2007) Tuberculosis susceptibility of diabetic mice. Am J Respir Cell Mol Biol 37: 518-524.

18. Vallerskog T, Martens GW, Kornfeld H (2010) Diabetic mice display a delayed adaptive immune response to Mycobacterium tuberculosis. J Immunol 184: 6275-6282. 
Citation: Yeh LT, Chuang YP, Chen SJ, Chu CC, Sytwu HK (2014) Diabetic Animal Models with Infectious Diseases: Focus on the Dysfunction of Immune System. J Diabetes Metab 5: 417 doi:10.4172/2155-6156.1000417

19. Podell BK, Ackart DF, Kirk NM, Eck SP, Bell C, et al. (2012) Non-diabetic hyperglycemia exacerbates disease severity in Mycobacterium tuberculosis infected guinea pigs. PLoS One 7: e46824.

20. Drachman RH, Root RK, Wood WB Jr (1966) Studies on the effect of experimental nonketotic diabetes mellitus on antibacterial defense. I Demonstration of a defect in phagocytosis. J Exp Med 124: 227-240.

21. Hebert JC, Coil JA Jr (1981) Increased susceptibility to pulmonary infection in alloxan diabetic mice. J Surg Res 31: 337-342.

22. Bagdade JD (1976) Phagocytic and microbicidal function in diabetes mellitus Acta Endocrinol Suppl (Copenh) 205: 27-34.

23. Bybee Jd, Rogers de (1964) The phagocytic activity of polymorphonuclear leukocytes obtained from patients with diabetes mellitus. J Lab Clin Med 64 $1-13$

24. Mowat A, Baum J (1971) Chemotaxis of polymorphonuclear leukocytes from patients with diabetes mellitus. N Engl J Med 284: 621-627.

25. Yamaguchi H, Oshio I, Osaki T, Kurata S, Yamamoto Y, et al. (2006) Development of diabetes in non-obese diabetic mice promotes Chlamydia pneumoniae dissemination from lung to peripheral blood. Int J Exp Pathol 87 121-129.

26. Ross R (1999) Atherosclerosis--an inflammatory disease. N Engl J Med 340 115-126.

27. Di Pietro M, Filardo S, De Santis FSessa R (2013) Chlamydia pneumoniae infection in atherosclerotic lesion development through oxidative stress: a brief overview. Int J Mol Sci 147: 15105-15120.

28. Patterson JE1, Andriole VT (1997) Bacterial urinary tract infections in diabetes. Infect Dis Clin North Am 11: 735-750.

29. Rosen DA, Hung CS, Kline KA, Hultgren SJ (2008) Streptozocin-induced diabetic mouse model of urinary tract infection. Infect Immun 76: 4290-4298.

30. Ramsey SD, Newton K, Blough D, McCulloch DK, Sandhu N, et al. (1999) Patient-level estimates of the cost of complications in diabetes in a managedcare population. Pharmacoeconomics 16: 285-295.

31. Yates C, May K, Hale T, Allard B, Rowlings N, et al. (2009) Wound chronicity, inpatient care, and chronic kidney disease predispose to MRSA infection in diabetic foot ulcers. Diabetes Care 32: 1907-1909.

32. Rich J, Lee JC (2005) The pathogenesis of Staphylococcus aureus infection in the diabetic NOD mouse. Diabetes 54: 2904-2910.

33. Park S, Rich J, Hanses F, Lee JC (2009) Defects in innate immunity predispose C57BL/6J-Leprdb/Leprdb mice to infection by Staphylococcus aureus. Infect Immun 77: 1008-1014.

34. Fang A, Hu SS, Endres N, Bradford DS (2005) Risk factors for infection after spinal surgery. Spine (Phila Pa 1976) 30: 1460-1465.

35. Liao J C, Chen W J, Chen L HNiu C C (2006) Postoperative wound infection rates after posterior instrumented spinal surgery in diabetic patients. Chang Gung Med J 295: 480-485.

36. Marchant MH Jr, Viens NA, Cook C, Vail TP, Bolognesi MP (2009) The impact of glycemic control and diabetes mellitus on perioperative outcomes after total joint arthroplasty. J Bone Joint Surg Am 91: 1621-1629.

37. Le NN, Rose MB, Levinson H, Klitzman B (2011) Implant healing in experimental animal models of diabetes. J Diabetes Sci Technol 5: 605-618.

38. Yano H, Kinoshita M, Fujino K, Nakashima M, Yamamoto Y, et al. (2012) Insulin treatment directly restores neutrophil phagocytosis and bactericidal activity in diabetic mice and thereby improves surgical site Staphylococcus aureus infection. Infect Immun 8012: 4409-4416.

39. Lovati AB, Drago L, Monti L, De Vecchi E, Previdi S, et al. (2013) Diabetic mouse model of orthopaedic implant-related Staphylococcus aureus infection. PLoS One 8: e67628.

40. Shah BR, Hux JE (2003) Quantifying the risk of infectious diseases for people with diabetes. Diabetes Care 26: 510-513.

41. Kitahara Y, Ishibashi T, Harada Y, Takamoto M, Tanaka K (1981) Reduced resistance to Pseudomonas septicaemia in diabetic mice. Clin Exp Immunol 43: $590-598$

42. Puliti M, Bistoni F, Orefici G, Tissi L (2006) Exacerbation of group B streptococcal sepsis and arthritis in diabetic mice. Microbes Infect 8: 2376-2383.
43. Osuchowski MF, Craciun FL, Schuller E, Sima C, Gyurko R, et al. (2010) Untreated type 1 diabetes increases sepsis-induced mortality without inducing a prelethal cytokine response. Shock 34: 369-376.

44. Jacob A, Steinberg ML, Yang J, Dong W, Ji Y, et al. (2008) Sepsis-induced inflammation is exacerbated in an animal model of type 2 diabetes. Int $\mathrm{J}$ Clin Exp Med 1: 22-31.

45. Spiller F, Carlos D, Souto FO, de Freitas A, Soares FS, et al. (2012) Î \pm 1 -Acid glycoprotein decreases neutrophil migration and increases susceptibility to sepsis in diabetic mice. Diabetes 61: 1584-1591.

46. Carlos D, Spiller F, Souto FO, Trevelin SC, Borges VF, et al. (2013) Histamine h2 receptor signaling in the pathogenesis of sepsis: studies in a murine diabetes model. J Immunol 191: 1373-1382.

47. Currie BJ, Fisher DA, Howard DM, Burrow JN, Lo D, et al. (2000) Endemic melioidosis in tropical northern Australia: a 10-year prospective study and review of the literature. Clin Infect Dis 31: 981-986.

48. Merianos A, Patel M, Lane JM, Noonan CN, Sharrock D, et al. (1993) The 1990-1991 outbreak of melioidosis in the Northern Territory of Australia: epidemiology and environmental studies. Southeast Asian J Trop Med Public Health 24: 425-435.

49. Suputtamongkol Y, Chaowagul W, Chetchotisakd P, Lertpatanasuwun $N$ Intaranongpai S, et al. (1999) Risk factors for melioidosis and bacteremic melioidosis. Clin Infect Dis 29: 408-413.

50. Suputtamongkol Y1, Hall AJ, Dance DA, Chaowagul W, Rajchanuvong A et al. (1994) The epidemiology of melioidosis in Ubon Ratchatani, northeast Thailand. Int J Epidemiol 23: 1082-1090.

51. Currie BJ, Ward L, Cheng AC (2010) The epidemiology and clinical spectrum of melioidosis: 540 cases from the 20 year Darwin prospective study. PLoS Negl Trop Dis 4: e900.

52. Hodgson KA, Morris JL, Feterl ML, Govan BL, Ketheesan N (2011) Altered macrophage function is associated with severe Burkholderia pseudomalle infection in a murine model of type 2 diabetes. Microbes Infect 13: 1177-1184.

53. Hodgson KA, Govan BL, Walduck AK, Ketheesan N, Morris JL (2013) Impaired early cytokine responses at the site of infection in a murine model of type 2 diabetes and melioidosis comorbidity. Infect Immun 81: 470-477.

54. Williams NL, Morris JL, Rush C, Govan BL, Ketheesan N (2011) Impact of streptozotocin-induced diabetes on functional responses of dendritic cells and macrophages towards Burkholderia pseudomallei. FEMS Immunol Med Microbiol 61: 218-227.

55. Yoshikawa T, Takano H, Naito Y Oyamada H, Ueda S, et al. (1992) Augmentative effects of tumor necrosis factor-alpha (human, natural type) on polymorphonuclear leukocyte-derived superoxide generation induced by various stimulants. Int J Immunopharmacol 148: 1391-1398.

56. Desruisseaux MS, Nagajyothi, Trujillo ME, Tanowitz HB, Scherer PE (2007) Adipocyte, adipose tissue, and infectious disease. Infect Immun 75: 1066-1078.

57. Wieland CW, Florquin S, Chan ED, Leemans JC, Weijer S, et al. (2005) Pulmonary Mycobacterium tuberculosis infection in leptin-deficient ob/ob mice. Int Immunol 17: 1399-1408.

58. Zeyda M, Stulnig TM (2007) Adipose tissue macrophages. Immunol Lett 112 $61-67$ 